удК 655.262:655.3.026.252

( О. І. Хмілярчук, к.т.н., доцент, М. О. Клішина, студентка, КП। ім. Ігоря Сікорського, Київ, Україна

\title{
АНАЛІЗ КОНСТРУКЦІЙ ВИДАНЬ \\ ЗІ ЗМІННИМИ ЕЛЕМЕНТАМИ БЛОКУ ТА СФЕРИ ЇХ ВИКОРИСТАННЯ
}

\begin{abstract}
У статті представлено результати аналізу конструкцій видань, що мають у своїй структурі змінні елементи. Проаналізовано сфери використання даного виду видань, а також розроблено їх узагальнену класифікацію.
\end{abstract}

Ключові слова: конструкція видання; змінні елементи видань; вид скріплення зошитів; конструкція зошитів; система застібок оригамі; скріплення на диски; скріпкошина.

\section{Постановка проблеми}

Людство стрімко розвивається, змінюється темп життя, збільшується кількість інформації та через це змінюється і ставлення людей до аналогових видань. Масове використання друкованих видань стає менш популярним, на зміну великим тиражам неяскравих примірників більш бажаним для користувача стає унікальне видання. Насамперед, головною відзнакою серед іншої продукції буде ексклюзивність видання, їі індивідуальність.

Загальними показниками видань зі змінними елементами, що відрізняють їх від видань за традиційним способом скріплення (тобто швейне (нитки або дріт) та клейове) є такий ряд переваг: можливість зміни елементів, поповнення новими, чистими аркушами та блоками, також є змога змінювати порядок зошитів, сторінок.

\section{Мета роботи}

Систематизація конструкцій видань зі змінними зошитами та встановлення тенденцій їх використання.

\section{Результати проведених досліджень}

Видання зі змінними зошитами $€$ корисним впровадженням у життя людей, саме вони можуть бути ефективно застосовані у різних сферах професійної діяльності, насамперед це економічна, педагогічна, наукова, творча та інші. Як приклад, такі конструкції зустрічаються у ділових журналах, бізнес органайзерах, виданнях, що використовуються під час подорожей.

За результатами аналізу ринку поліграфічної продукції, варто зазначити, що конструкції зі змінними зошитами не досить популярні, але все більш розвиваються. Відомими нині конструкціями $€$ такі: видання зі скріпленням на кільця, на металеві тримачі, на

() $2018 p$. 
Рис. 1. Конструкція видання, що скріплюється на кільця: 1 - сторінка, 2 - кільця, 3 - перфорація, 4 - палітурка, 5 - металева основа для кілець

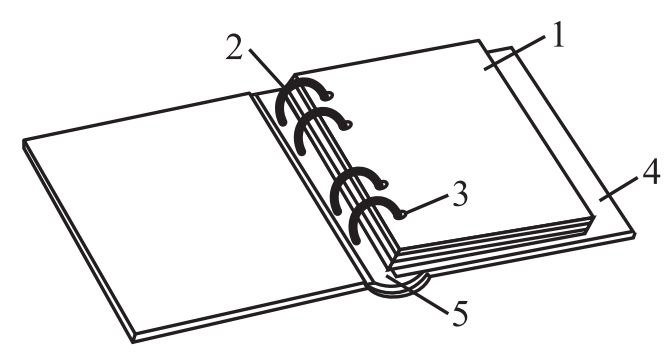

резинки, за допомогою пластикового диску, видання з магнітним корінцем, видання зі стрижнем, зі скріпкошиною, з системою застібок оригамі.

Скріплення на кільця [1] використовується у рекламних, виробничо-практичних та науково-популярних виданнях. Конструкція видання, що скріплюється на кільця, складається зі сторінок (що 3 корінцевого краю мають перфорацію), кілець (що скріплюють зошити) та палітурки типу 5 (рис. 1).

Видання зі скріпленням на металеві тримачі [2] застосовуються, переважно, як довідкові, не призначені для суцільного читання. Конструкція видання зі скріпленням на металеві тримачі (рис. 2) складається із зошитів (що скріплені на скобу), метале- вого тримача (скріплює зошити у корінці) та палітурки типу 5 (із покривним матеріалом на сторонки палітурки).

У рекламних виданнях зустрічається використання магнітного корінця [3, 4]; конструкція видання, що скріплюється за допомогою сталевого стрижня та магнітних вставок на сторінках, складається з магнітного стрижня, сторінок (з корінцевого боку яких вставлена металева вставка або магнітний вініл) та палітурки типу 7, відставом слугує магнітний стрижень, що є основою скріплення зошитів (рис. 3).

Для організації дозвілля використовують видання, що скріплюється на резинки [5]. Конструкція характеризується зошитами (що скріплені на скобу чи дріт),

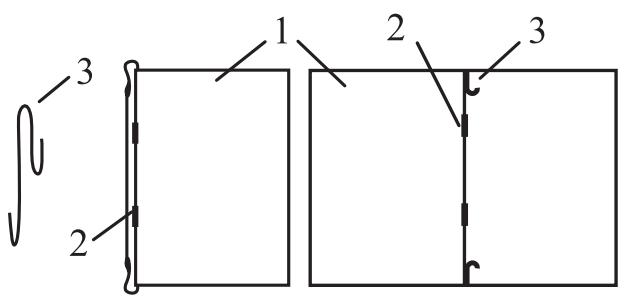

a

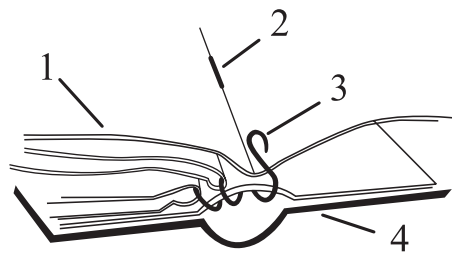

B

Рис. 2. Конструкція видання зі скріпленням на металеві тримачах: a - вигляд зошита в закритому стані, б - вигляд зошита в розкритому стані; в - вигляд видання у зібраному вигляді $(1-$ зошит, 2 - скоба, 3 - металевий тримач, 4 - палітурка) 


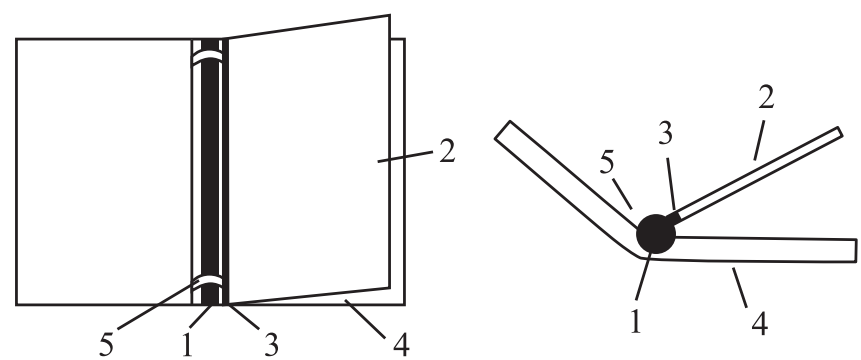

Рис. 3. Конструкція видання, що скріплюється за допомогою сталевого стрижня та магнітних вставок на сторінках: 1 - магнітний стрижень, 2 - сторінка, 3 - металева вставка на сторінці, 4 - палітурка, 5 - стрічка-тримач магнітного стрижня
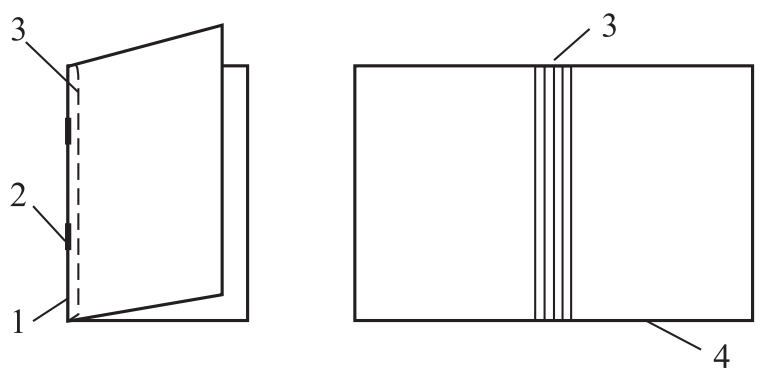

Рис. 4. Конструкція видання зі скріпленням на резинки: 1 - зошит, 2 - скоба, 3 - резинка, 4 - палітурка

резинками (що скріплюють зошит у корінці) та палітуркою типу 5 (рис. 4).

3 переліку виробничо-практичних зустрічається видання зі скріпкошиною, яке складається із зошитів (що скріплені на скобу чи дріт), скріпкошини (скріплення зошита у корінці - на кліпсу чи скріпкошину), висічки для кращого розгортання видання та палітурки типу 5 [6] (рис. 5).

Видання зі стрижнем призначені для організації дозвілля. Конструкція видання зі стрижнем (рис. 6) складається із зошитів (що скріплені на скобу чи дріт), блоку зошитів (тип скріплення зошита у корінці - де-

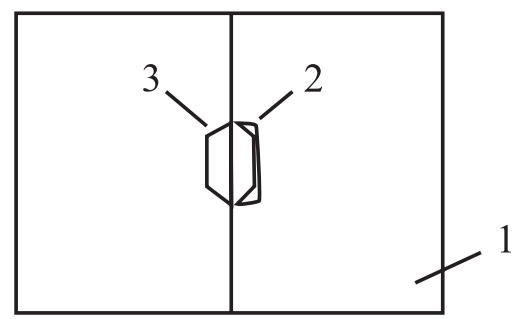

Рис. 5. Конструкція видання зі скріпкошиною: 1 - зошит, 2 - скріпкошина, 3 - висічка для кращого розгортання скріпкошини 


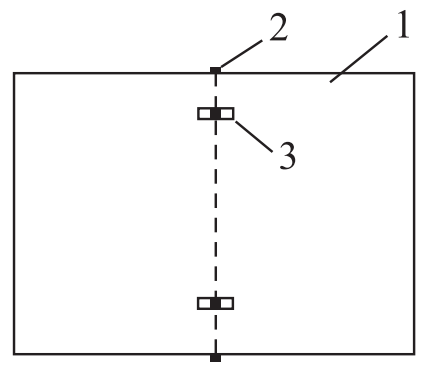

a

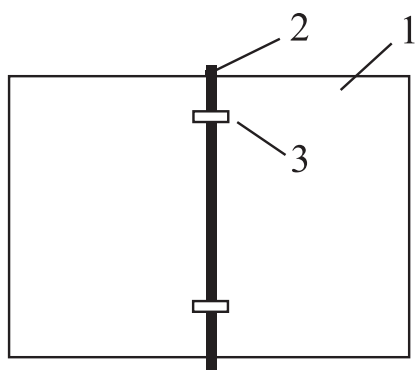

б

Рис. 6. Конструкція видання зі стрижнем: a - вигляд видання ззовні в розкритому стані, б - вигляд зсередини в розкритому стані; 1 - зошит, 2 - стрижень, 3 - висічка

рев'яний, пластиковий чи металевий стрижень) та палітурки типу 7 [7]. Для встановлення стрижня у корінець застосовують висічку на середньому фальці сторінок.

У науково-виробничих, довідникових та рекламних виданнях зустрічається конструкція видання із системою застібок оригамі [8], що складається із зошитів (скріплені на скобу чи дріт), застібки оригамі (тип скріплення зошита у корінці) та палітурки типу 5 (рис. 7).
Видання, що скріплюється за допомогою пластикового диску $[9,10]$ зображено на рис. 8. За видом видань цільового призначення розглянута конструкція може застосовуватися для видань організації дозвілля. Конструкція видання характеризується за такими показниками: тип палітурки - 5; тип скріплення зошита - на пластиковий диск, що звужений від центру та має потовщені межі кола.

Серед тенденцій майбутнього у конструюванні книг необхідно підкреслити, що, не зважаючи

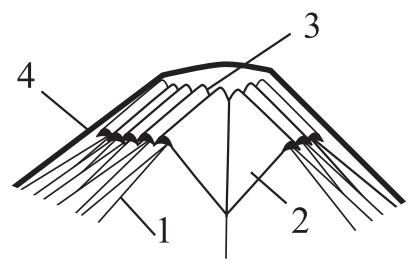

a

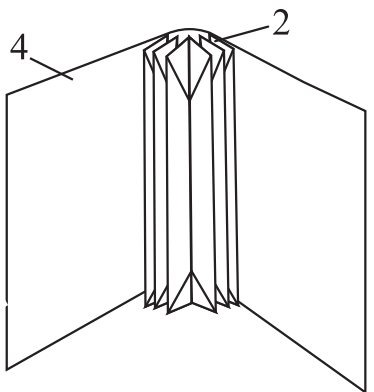

6

Рис. 7. Конструкція видання із системою застібок оригамі: а - вигляд клапанів видання всередині в розкритому стані, б - зовнішній вигляд палітурки в розкритому стані; 1 - зошит, 2 - застібка оригамі, 


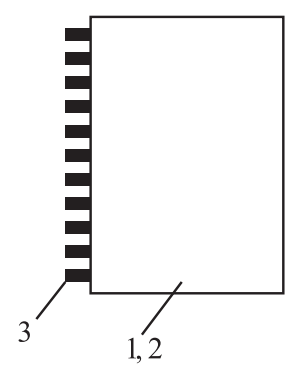

a

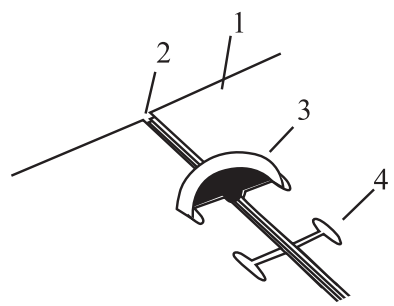

б

Рис. 8. Конструкція видання зі скріпленням на диск: а - видання в закритому вигляді, б - видання у відкритому вигляді; 1 - сторінка, 2 - блок, 3 - диск, 4 - перфорація

на те, що книга 3 давнини має традиційну конструкцію, перспектива розвитку видання вказує на тенденції змін у структурі книги, її скріплення, використання більш різноманітних матеріалів. Запропоновані видання мають складну конструкцію та оригінальне відтворення зовнішніх елементів книги, вони є більш зручними, унікальними, але й водночас дорожчими та призначені як подарункові видання. Узагальнена класифікація видань зі змінними зошитами представлена на рис. 9.

Підводячи підсумки проведеного дослідження, необхідно зазначити, що на даний час представлені на поліграфічному ринку видання $€$ не завжди якісними, на відміну від наведених конструкцій видань. Звісно, економічно вигідними залишаються вже існуючі популярні книги на ринку, але унікальність та виразність розглянутої продукції збільшує вірогідність купівлі книги.

\section{Висновки}

Проведене дослідження існуючих конструкцій видань зі змінними зошитами показало істотні переваги проаналізованих конструкцій у певних сферах життя людини. Найчастіше використання даних видів зустрічається у випуску білової продукції, а також сфери дозвілля та розваг.

На основі проведеного аналізу розроблено узагальнену класифікацію видань зі змінними елементами, що поєднала у собі технологічні особливості їх виготовлення, матеріали, елементи конструкції та основне призначення.

\section{Список використаних джерел/References}

1. Refillable notebook with release mechanism. US $8,876,423$ B2. Int. Cl. B42F 13/06, B42F 13/02, B42F 13/165 Filed: Oct. 18, 2011. Pub. Date: Nov. 4, 2014 [in English].

2. Mobile binding. US 4589682. Int. Cl. B42D 17/00. Filed: Jul. 16, 1985. Pub. Date: May 20, 1986 [in English]. 


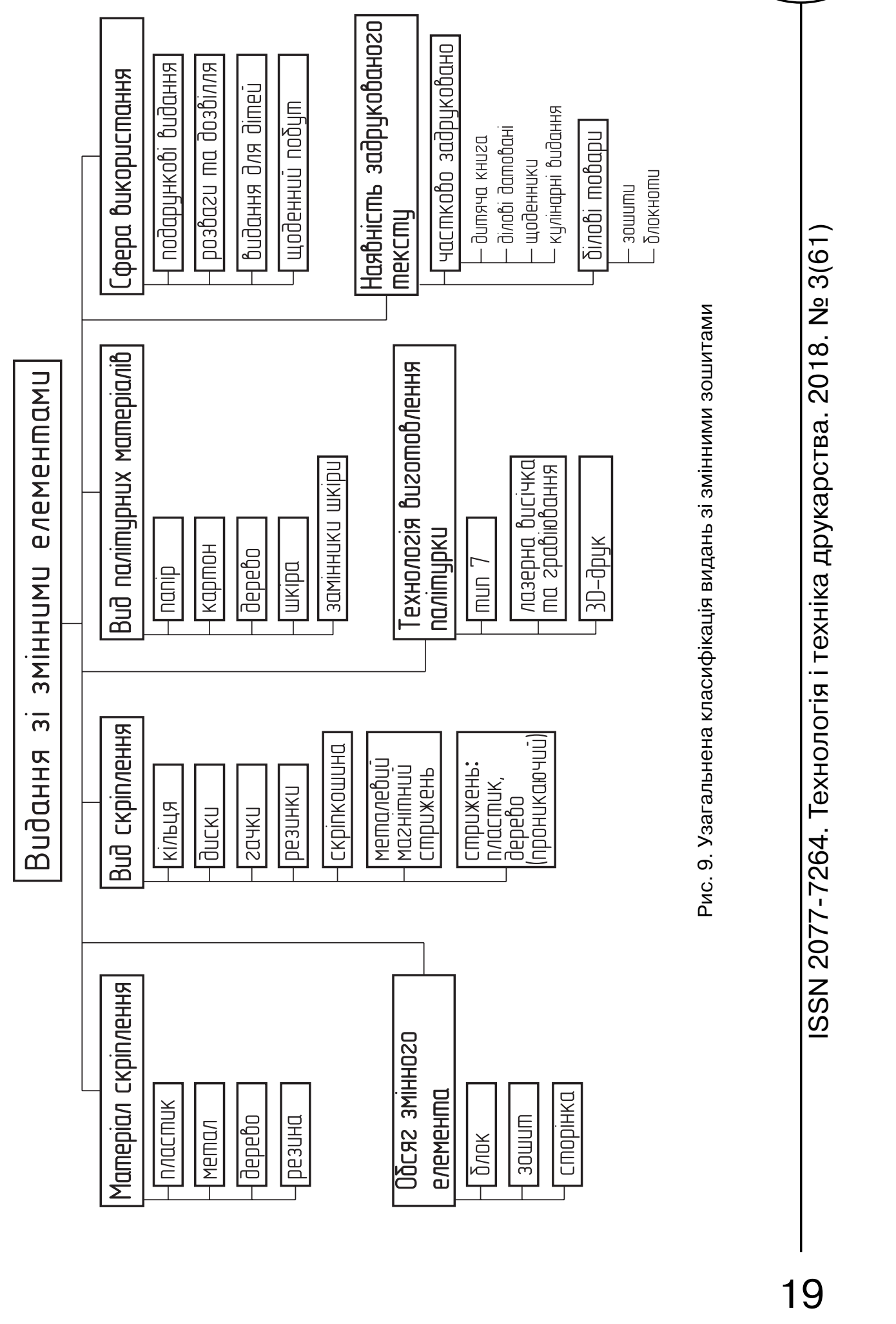


3. Magnetically bound medium with reattachable pages. US $2015 / 0224806$ A1. Int. Cl: B42D 13/00; D21H 17/25; D21H 17/67; D21H 17/68; B42D 1/00; D21H 17/00/. Filed: Feb. 12, 2014. Pub. Date: Aug. 13, 2015 [in English].

4. Rekonect Notebook: The Magnetic Lifestyle. Retrieved from https://www.kickstarter.com/projects/273274561/rekonect-notebook-themagnetic-lifestyle [in English].

5. Apparatus for holding greeting cards. US 006108952A. Int. Cl: G09F 1/10. Filed: Mar. 26, 1997. Pub. Date: Aug. 29, 2000 [in English].

6. Securing tool with swing clip and indicia area. US 2007/0086839 A1. Int. Cl: B42F 3/2. Filed: Sep. 26, 2006. Pub. Date: Apr. 19, 2007 [in English].

7. Consecotaleophobia - Editorial Design. Retrieved from http://clc.am/ay0n7Q [in English].

8. Encuadernación. Colección de libretas con hojasextraibles. Retrieved from https://tinyurl.com/yb8d5pwt [in English].

9. Spiral bound notebook with removable sheets. US 2011/0233913 A1 Int. Cl. B42D 1/0/ Filed: Mar. Mar. 23, 2010. Pub. Date: Sep. 29, 2011 [in English].

10. One-piece rigid covers for disc-bound fold-over binding system and use of composite material for making the same. EP 3222437 A1 Int. Cl. B42F 3/00, B42F 13/00 Filed: 23.03.2017. Pub. Date: 27.09.2017. Bulletin 2017/39 [in English].

\section{В статье представлен анализ конструкций изданий, имеющих в своей структуре сменные элементы. Проанализированы сферы использования данного вида изданий, а также разработано их обобщенную классификацию.}

\section{Ключевые слова: конструкция издания; сменные элементы изданий; вид скрепления тетрадей; конструкция тетрадей; система застежек оригами; скрепление на диски; скрепкошина.}

The article presents the results of the analysis of the contractures of books and others editions, which have variable elements in its structure. Areas of use of this type of editions have been analyzed, and their generalized classification has been developed.

Keywords: construction of edition; variable elements of editions; kind of binding of notebooks; construction of notebooks; origami fastening system; fastening to discs; pinworm. 